\title{
Revision of chamois infection by lung nematodes under ecological conditions of national parks of Slovakia with respect to ongoing global climate changes
}

\author{
A. ŠTEFANČÍKOVÁ ${ }^{1}$, B. CHOVANCOVÁ ${ }^{2}$ B. HÁJEK ${ }^{3}$, V. DUDIŇÁK ${ }^{4}$, V. ŠNÁBEL ${ }^{1}$
}

\author{
${ }^{1}$ Institute of Parasitology, Slovak Academy Sciences, Hlinkova 3, 04001 Košice, Slovak Republic, \\ E-mail: astefan@saske.sk; ${ }^{2}$ Tatra National Park Research Station, 05960 Tatranská Lomnica, Slovak Republic; \\ ${ }^{3}$ Government Slovak Paradise National Park, Letecká 3, 05961 Spišská Nová Ves, Slovak Republic; \\ ${ }^{4}$ T-Systems Slovakia Ltd., Žriedlová 13, 04001 Košice, Slovak Republic
}

\section{Summary}

The aim of our study was to analyze helminth status and to evaluate ecological conditions for infections of chamois with lung nematodes in national parks of Slovakia during global warming. The autopsies and larvoscopic examination of faeces collected from localities inhabited by Tatra chamois (Rupicapra rupicapra tatrica) in Tatra National Park (TANAP) and Low Tatras National Park (NAPANT) revealed the presence of following protostrongylids: Muellerius capillaris, Neostrongylus linearis and the specific chamois species Muellerius tenuispiculatus. Same species of lung nematodes were found in introduced chamois of Alpine origin (Rupicapra rupicapra rupicapra) in the Slovak National Park Vel'ká Fatra (NAPVF) and the Slovak Paradise National Park (NAPSR), and in the latter park also geohelminth Dictyocaulus viviparus was sporadically determined. The mean prevalence of lung nematodes in individual parks varied from 70.9 to $97.2 \%$. The mean number of L1 larvae per $1 \mathrm{~g}$ of faeces in Tatra chamois from TANAP in Belianske Tatras and in Alpine subspecies from NAPSR corresponded to a high level of infection (120.3 and 110.1, respectively). In other studied biotopes the mean number of L1 larvae $(19.4-42.5)$ revealed the moderate infection. Although no significant differences concerning levels of infection within the monitored years were observed, the level of infection during the summer was significantly lower than that during spring and autumn periods. The variety of snail species as the intermediate hosts of lung nematodes provide suitable conditions for the development of lung nematodes in the all studied Slovak National Parks. Global climatic changes have also likely contributed to an increase of infectivity rate.

Keywords: Muellerius tenuispiculatus; Muellerius capillaris; Neostrongylus linearis; chamois; National Parks; Slovakia

\section{Introduction}

Tatra chamois (Rupicapra rupicapra tatrica Blahout, 1971), a significant representative of the original glacial fauna, has been classified as a critically endangered species (IUCN Red List of Threatened Species) (Caprinae Specialist Group 2000) and as a threatened species also by EMA (European Mammal Assessment) (Aulagnier et al., 2008). At present, in the territory of Slovakia, two small and isolated populations in the High and Low Tatras are formed by this rare endemic species. Furthermore, small populations of the introduced Alpine subspecies are established in the national parks of the Slovak Paradise and Vel'ká Fatra. Both the Tatras and Alpine populations require permanent and complex protection, and it is in particular the Tatra chamois that needs urgent conservation measures. The most significant factors threatening their existence include food, anthropogenic factors, predators, health conditions, loss of suitable biotopes, environmental pollution, climate conditions involving global climate changes (Blahout, 1976, 1977; Radúch, 2002; Gašinec, 2002) and, on a large scale, infections with parasitic diseases (Sattlerová-Štefančíková, 2005).

A detailed study of ecology, morphology and pathomorphology of lung nematodes has enabled the long term comprehensive evaluation of impact of parasitoses encountered in rare Tatra chamois subspecies, with several simultaneously acting ecological factors being considered. Moreover, it has enabled to spotlight the role of these parasites in a continuing decline in the chamois population not only in the Tatras National Park and in the introduced populations of Tatra chamois in the Low Tatras National Park (Sattlerová-Štefančíková, 1982, 1987; Štefančíková, 1994; Štefančíková et al., 1999; Sattlerová-Štefančíková, 2005), but also in other countries (Hörning, 1975; Clark \& Clarke, 1981; Genchi et al., 1984; Cancrini et al., 1985; Diez et al., 1990; Nocture et al., 1998; PanaytovaPencheva, 2006). 
Changing ecological conditions, including a forthcoming climate changes, could signal the changes in species composition, distribution, and level of infection with different pathogens in different hosts. The objective of the study was to analyze helminth burden and to evaluate ecological conditions of parasitic infection with lung nematodes in chamois living in the national parks of Slovakia during global warming event.

\section{Material and methods}

\section{Characteristics of chamois habitats}

The Tatras National Park (TANAP) constitutes the northernmost and the highest part of the $1200 \mathrm{~km}$ long arch of the Carpathians. As far as the distribution of chamois is concerned, the High Tatras, West Tatras and Belianske Tatras, differing in their geographical, orographical, geological, trophic and climatic conditions, are the most important sites. The habitats under study are situated at the subalpine to alpine vegetation level with an altitude of $1749-2655 \mathrm{~m}$ above sea level. The Tatras climate is continental with typical features of an Alpine climate, for which extreme fluctuations in temperature are characteristic.

The Low Tatras National Park (NAPANT) is located in Central Slovakia, between the Váh river and the Hron river valleys. Its separation from the High Tatras was caused by the lower activity of glaciers and typical summits (jokuls) occuring less frequently than those in the High Tatras. Geological composition is a set of prevailing granites and crystalline schists, but limestones and dolomites are infrequent (Radúch \& Karč, 1981; Štefančíková, 1994; Sattlerová-Štefančíková, 2005). The habitats are situated at the subalpine to alpine vegetation level with an altitude of $1886-2003 \mathrm{~m}$ above sea level. The climate is rather similar to that in the High Tatras (Houdek \& Bohuš, 1976). The Slovak Paradise National Park (NAPSR) is situated in the northwestern part of the Spiš Ore Mountains, presenting a part of the Slovak Ore Mountains, which belong to the central zone of the Western Carpathians. Though not classified at the rank of high-mountains parks (lying at 400 $-1200 \mathrm{~m}$ above sea level), it is regarded as the area having an alpine character thanks to its well-known canyons with waterfalls and ravines. It is characterized as a biotope with a mesozoic bedrock, consisting largely of Triassic limestones and dolomites. Chamois frequently occur in the localities situated at the altitude of $660-1057 \mathrm{~m}$ above sea level. The current population contains approx. 100 chamois specimens. The climate is continental (Houdek \& Bohuš, 1976).

The National Park Vel'ká Fatra (NAPVF) and its protective zone comprise most of the Greater Fatra Range, which belongs to the Outer Western Carpathians. The core of the range constitutes granite that reaches the surface only in certain places; more common are various slates creating gently modelled ridges and summits and limestone and dolomite rocks constituting a rough and picturesque terrain. The habitats of introduced alpine chamois are situated at the level with an altitude of $800-1350 \mathrm{~m}$ above sea level. The current population numbers approx. 53 chamois. The climate is continental (Houdek \& Bohuš, 1976). Mountainous ranges of chamois habitats of Slovakia are depicted in Fig. 1.

\section{Necropsy and faecal samples}

During 2008 - 2010, 1248 chamois faecal samples (622 samples from TANAP, 229 from NAPANT, 249 from NAPSR and 148 from NAPVF) were microscopically examined for the first stage larvae of lung nematodes. The faeces were collected at chamois habitats only during three

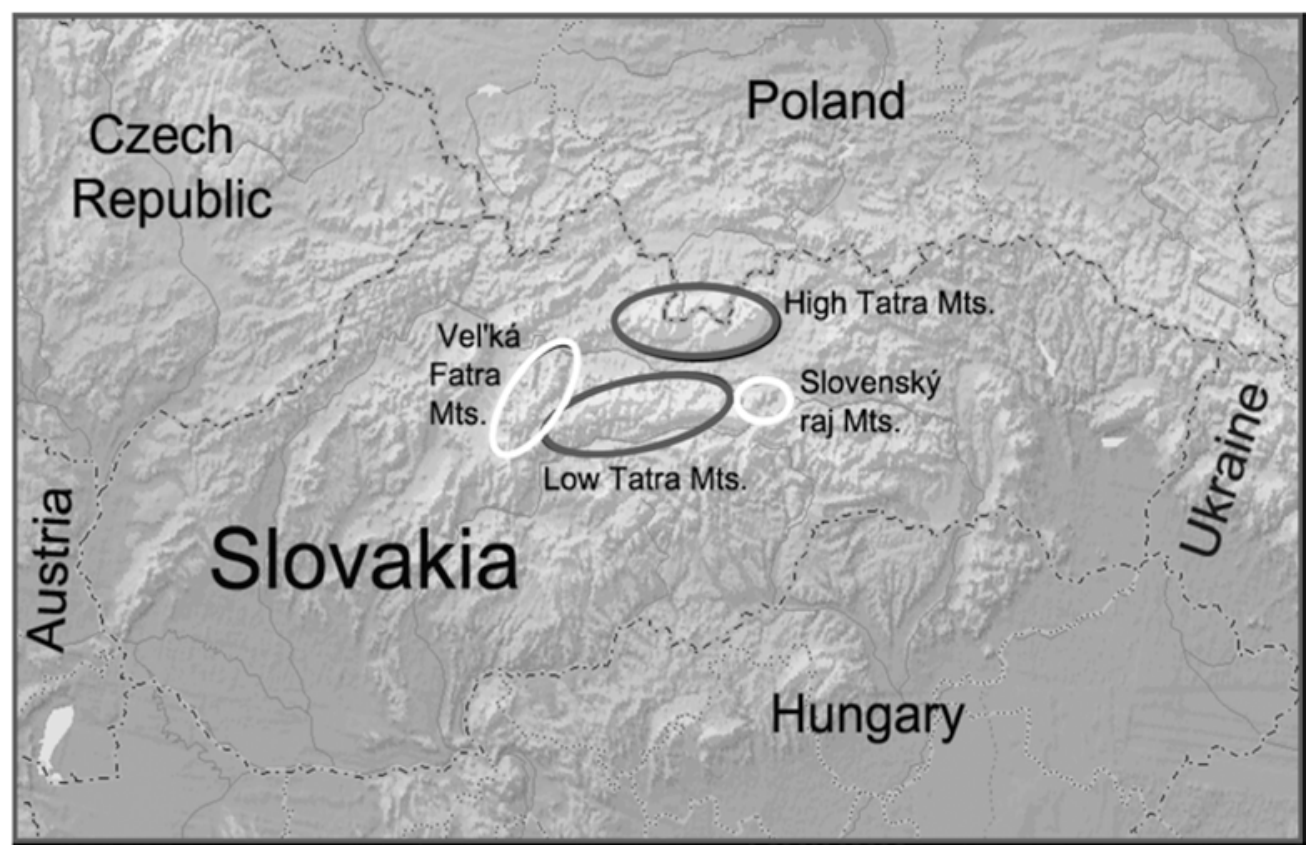

Fig. 1. Mountainous ranges of Slovakia inhabited by chamois 
seasons, because of the inaccessibility of this area in winter (Tables 1, 2). The five lungs were obtained from TANAP and NAPANT after natural death, the seven lungs from NAPSR and NAPVF by selective shooting. The examination of adults and the isolation of L1 larvae from faeces and lungs, its counting and evaluation of infection level were performed using methods previously described by Štefančíková (1994, 1999). Briefly, lungs were dissected and adult nematodes recovered as follows: worms were isolated by placing about $5 \times 5 \mathrm{~mm}$ large pieces of pathologically altered lung tissue into $0.2 \%$ Verzen (Chelaton) solution for $30 \mathrm{~min}$ to disintegrate tissue elements. The tissue was then pressed between two slides and thus prepared material examined under microscope. Larvae from lungs and faeces were isolated by Baermann's method. They were counted by a micropipette of the micromanipulator under a microscope with 100x magnification. In case their number was fewer than 100 all of them were identified. If the number of larvae was higher approximately $30 \%$ were studied. The degree of infection was classified by the number of larvae per gram of lung tissue or faeces: up to 10 larvae - low level of infection; up to 100 larvae - moderate infection; over 100 larvae - heavy infection.

\section{Statistical analyses}

Differences in the prevalence of lung nematodes in the biotope were statistically evaluated by chi-square $\left(\chi^{2}\right)$ test. ANOVA test was used to confirm statistically significant difference among at least three tested variables in factors (years, biotopes, seasons and their possible combinations). Tukey's Honestly Significant Difference test for unequal N was used to find differences among samples if ANOVA test has confirmed significant difference among them. Student's t test was used to confirm significant difference between two chamois' species. A probability of less than 0.05 indicated a statistically significant difference. For cluster analysis biotope medians were used. Complete linkage (furthest neighbour) method with Euclidean dis-

Table 1. Prevalences of lung nematodes in faeces from chamois herds in Tatra chamois by habitats and species of nematodes

\begin{tabular}{ccccc}
\hline \multirow{2}{*}{ Habitat } & \multirow{2}{*}{ No.exam. } & \multicolumn{3}{c}{ Prevalence (\%) } \\
\cline { 3 - 5 } & & Lung nematodes & Muellerius spp & N. linearis \\
\hline High Tatras: & $\mathbf{2 5 8}$ & $\mathbf{7 0 . 9}$ & $\mathbf{6 8 . 2}$ & $\mathbf{3 8 . 0}$ \\
\hline Skalnatá dolina & 20 & 70.0 & 65.0 & 35.0 \\
Vel'ká Svišt'ovka & 16 & 62.5 & 62.5 & 31.3 \\
Malá Studená dolina & 36 & 64.0 & 64.0 & 33.3 \\
Velická dolina & 38 & 73.6 & 65.8 & 34.2 \\
Furkotská dolina & 27 & 70.4 & 70.4 & 44.4 \\
Mlynická dolina & 46 & 76.1 & 76.1 & 41.3 \\
Batizovská dolina & 24 & 58.3 & 58.3 & 37.5 \\
Mengušovská dolina & 26 & 69.2 & 65.4 & 38.5 \\
Červená dolinka & 19 & 94.7 & 94.7 & 47.4 \\
Tristárska dolina & 6 & 66.6 & 66.6 & 33.3 \\
\hline West Tatras: & $\mathbf{7 8}$ & $\mathbf{7 4 . 3}$ & $\mathbf{6 7 . 9}$ & $\mathbf{3 7 . 2}$ \\
\hline Hladké Sedlo & 16 & 68.7 & 62.5 & 31.3 \\
Hlinská dolina & 17 & 76.5 & 70.6 & 29.4 \\
Skalina & 18 & 77.7 & 72.2 & 44.4 \\
Salatin & 21 & 76.2 & 71.4 & 38.1 \\
Holý Kameň & 6 & 66.6 & 66.6 & 33.3 \\
\hline Belianske Tatras: & $\mathbf{2 8 6}$ & $\mathbf{9 6 . 8}$ & $\mathbf{9 5 . 4}$ & $\mathbf{5 4 . 2}$ \\
\hline Zadné Jatky & 83 & 97.6 & 97.6 & 63.8 \\
Skalné Vráta & 43 & 95.3 & 93.02 & 53.5 \\
Ždiarska Vidla & 54 & 96.3 & 96.3 & 51.8 \\
Hlúpy & 61 & 98.4 & 98.4 & 52.4 \\
Havran & 45 & 95.5 & 88.8 & 42.2 \\
\hline Total TANAP & $\mathbf{6 2 2}$ & $\mathbf{8 3 . 3}$ & $\mathbf{8 0 . 7}$ & $\mathbf{4 5 . 3}$ \\
\hline Dereše & 41 & 92.6 & 87.8 & 41.5 \\
Chopok & 43 & 90.7 & 90.7 & 44.2 \\
Chabenec & 35 & 91.4 & 88.6 & 57.1 \\
Ďumbier & 34 & 85.3 & 85.3 & 47.05 \\
Botliská & 34 & 86.5 & 75.7 & 35.1 \\
\hline NAPANT & $\mathbf{2 2 9}$ & $\mathbf{8 6 . 0}$ & $\mathbf{8 0 . 8}$ & $\mathbf{4 2 . 4}$ \\
\hline
\end{tabular}


Table 2 Prevalences of lung nematodes in faeces from chamois herds in Alpine chamois by habitats and species of nematodes

\begin{tabular}{ccccc}
\hline \multirow{2}{*}{ Habitat } & \multirow{2}{*}{ No.exam. } & \multicolumn{3}{c}{ Prevalence (\%) } \\
\cline { 3 - 5 } & 57 & Lung nematodes & Muellerius spp. & N. linearis \\
\hline Suchá Belá & 42 & 96.5 & 94.7 & 47.4 \\
Stratená-Sokolica & 47 & 97.6 & 97.6 & 42.8 \\
Stratená-Dedinky & 49 & 97.8 & 97.8 & 46.8 \\
Srnčie Skaly & 54 & 95.9 & 95.9 & 46.9 \\
Kysel' & $\mathbf{2 4 9}$ & 98.1 & 98.1 & 46.2 \\
\hline Total NAPSR & 47 & $\mathbf{9 7 . 2}$ & $\mathbf{9 6 . 8}$ & 46.2 \\
\hline Horné Piesky & 25 & 87.2 & 87.2 & 44.0 \\
Duurd'ášová & 27 & 84.0 & 80.0 & 44.4 \\
Štrochy & 31 & 77.7 & 77.7 & 51.6 \\
Suchý Jasienok & 18 & 90.3 & 87.1 & 33.3 \\
Pekárová Skala & $\mathbf{1 4 8}$ & $\mathbf{8 4 . 5}$ & 72.2 & $\mathbf{4 5 . 3}$ \\
\hline Total NAPVF & & & $\mathbf{8 2 . 4}$ &
\end{tabular}

tance measure was used to build clusters. All tests and statistical procedures were performed using STATISTICA 6 analysis software (StatSoft Inc., 2001).

\section{Results}

Dissection and larvoscopic examination in both Tatra and Alpine chamois confirmed the presence of following lung nematodes: M. capillaris, M. tenuispiculatus and Neostron- gylus linearis and occasionally D. viviparus in Alpine chamois in the Slovak Paradise. The prevailing species in all studied national parks were Muellerius spp., while $N$. linearis occurred twice less frequently. The mean prevalence of lung nematodes varied from $70.9 \%$ to $97.2 \%$. In Tatra chamois, the significantly higher mean prevalence was recorded in TANAP, an area of Belianske Tatras $(96.8 \%)$ and NAPANT $(86.0 \%)$, in Alpine chamois in NAPSR $(97.2 \%)$ and NAPVF $(84.5 \%)$ when compared to

Table 3. Prevalences of lung nematodes in faeces from chamois herds in Tatra and Alpine chamois by years and seasons

\begin{tabular}{cccccccccc}
\hline \multicolumn{7}{c}{} & \multicolumn{7}{c}{ Years } \\
\hline Biotop & Season & 2008 & \multicolumn{3}{c}{2009} & & 2010 & & Total \\
\hline & & $\begin{array}{c}\text { No. } \\
\text { exam./poz. }\end{array}$ & $\%$ & $\begin{array}{c}\text { No. } \\
\text { exam./poz. }\end{array}$ & $\%$ & $\begin{array}{c}\text { No. } \\
\text { exam./poz }\end{array}$ & $\%$ & $\begin{array}{c}\text { No. } \\
\text { exam./poz }\end{array}$ & $\%$ \\
\hline \multirow{5}{*}{ TANAP } & Spring & $95 / 86$ & 90.5 & $33 / 28$ & 84.8 & $106 / 95$ & 90.0 & $234 / 209$ & 89.3 \\
& Summer & $53 / 35$ & 66.0 & $29 / 16$ & 55.2 & $49 / 30$ & 61.2 & $131 / 81$ & 61.8 \\
& Autumn & $114 / 103$ & 90.3 & $46 / 36$ & 78.3 & $97 / 89$ & 91.7 & $257 / 228$ & 88.7 \\
& Total & $262 / 224$ & 85.5 & $108 / 80$ & 74.1 & $252 / 214$ & 84.9 & $622 / 518$ & 83.3 \\
& & & & & & & & & \\
& Spring & $27 / 24$ & 88.8 & $28 / 25$ & 89.3 & $29 / 26$ & 89.6 & $84 / 75$ & 89.3 \\
NAPANT & Summer & $25 / 20$ & 80.0 & $19 / 15$ & 78.9 & $16 / 12$ & 75.0 & $59 / 46$ & 78.0 \\
& Autumn & $24 /$ & 87.5 & $29 / 26$ & 89.6 & $32 / 28$ & 87.5 & $86 / 76$ & 88.4 \\
& Total & $76 / 65$ & 85.5 & $76 / 66$ & 86.8 & $77 / 66$ & 85.7 & $229 / 197$ & 86.0 \\
& & & & & & & & & \\
& Spring & $38 / 37$ & 97.4 & $32 / 31$ & 96.9 & $27 / 26$ & 96.3 & $97 / 94$ & 96.9 \\
& Summer & $17 / 16$ & 94.1 & $21 / 20$ & 95.2 & $19 / 18$ & 94.7 & $57 / 54$ & 94.7 \\
& Autumn & $34 / 34$ & 100.0 & $28 / 27$ & 96.4 & $33 / 33$ & 100.0 & $95 / 94$ & 98.9 \\
& Total & $89 / 87$ & 97.7 & $81 / 78$ & 96.3 & $79 / 77$ & 97.5 & $249 / 242$ & 97.2 \\
& & & & & & & & & \\
& Spring & $14 / 12$ & 85.7 & $10 / 8$ & 80.0 & $11 / 9$ & 81.8 & $35 / 29$ & 82.8 \\
NAPVF & Summer & $17 / 12$ & 70.6 & $14 / 9$ & 64.3 & $16 / 14$ & 87.5 & $47 / 35$ & 74.5 \\
& Autumn & $22 / 20$ & 90.9 & $23 / 22$ & 95.6 & $21 / 19$ & 90.5 & $66 / 61$ & 92.4 \\
& Total & $53 / 44$ & 83.0 & $47 / 39$ & 82.5 & $48 / 42$ & 87.5 & $148 / 125$ & 84.5 \\
\hline
\end{tabular}


Table 4. Statistical results (Biotopes in Years and Seasons)

\begin{tabular}{lllc}
\hline $\begin{array}{l}\text { Tested group } \\
\text { (Biotopes) }\end{array}$ & F value & df; $\mathrm{N}$ & $\mathrm{P}$ \\
\hline 2008 & 84.344 & $5 ; 434$ & $<0.001^{* * *}$ \\
2009 & 47.473 & $5 ; 427$ & $<0.001 * * *$ \\
2010 & 70.719 & $5 ; 427$ & $<0.001 * * *$ \\
Spring & 70.411 & $5 ; 426$ & $<0.001^{* * *}$ \\
Summer & 93.794 & $5 ; 428$ & $<0.001^{* * *}$ \\
Autumn & 67.053 & $5 ; 412<0.001 * * *$ \\
\hline
\end{tabular}

chamois in the High Tatras and the West Tatras $(70.9 \%$, $74.3 \%$, respectively) ( $\chi^{2}, \mathrm{p}<0.001$, respectively). The mean prevalence of lung nematodes showed a similar pattern when overall values and values according to species tuations were analyzed, a significantly higher prevalence was recorded in all summer seasons in TANAP $(\mathrm{p}<0.05)$ and in summer 2009 NAPVF $(\mathrm{p}<0.05)$ (Table 3$)$.

The level of chamois infection differed in studied biotopes (Table 4). The mean number of L1 larvae per $1 \mathrm{~g}$ of faeces in Tatra chamois in TANAP in the Belianske Tatras and in Alpine subspecies in NAPSR comply with rank for high level of infection $(120.3 \pm 73.2-164.04 \pm 67.6,110.1 \pm$ $74.1-141.6 \pm 84.3$, respectively). This value was significantly higher than level of infection in Tatra chamois in the High Tatras $(42.5 \pm 50.8-50.1 \pm 54.04)$, the West Tatras $(19.4 \pm 29.4-33.8 \pm 60.1)$ and the Low Tatras $(36.8 \pm$ $27.3-52.2 \pm 37.5)$ and in Alpine subspecies in NAPVF $(34.9 \pm 21.9-40.04 \pm 28.3)$, where the mean number of L1 larvae revealed the moderate infection. Although no significant differences at levels of infection within the monitored years were observed, the level of infection during the summer was significantly lower than during

Table 5. Statistical results (Years, Seasons)

\begin{tabular}{llll}
\hline Tested group (tested categories) & F value & df; N & P \\
\hline Years (2008, 2009, 2010) & 1.729 & $2 ; 1280$ & 0.178 \\
Seasons (Spring, Summer, Autumn) & 13.592 & $2 ; 1280$ & $<0.001^{* * *}$ \\
2008 (Spring, Summer, Autumn) & 2.428 & $2 ; 435$ & 0.089 \\
2009 (Spring, Summer, Autumn) & 18.957 & $2 ; 429$ & $<0.001^{* * *}$ \\
2010 (Spring, Summer, Autumn) & 1.023 & $2 ; 408$ & 0.361 \\
Spring (2008, 2009, 2010) & 1.747 & $2 ; 428$ & 0.175 \\
Summer $(2008,2009,2010)$ & $6.920^{* *}$ & $2 ; 430$ & $0.0011^{* *}$ \\
Autumn $(2008,2009,2010)$ & 1.102 & $2 ; 414$ & 0.333 \\
\hline
\end{tabular}

were considered. Considering the national parks, significant differences were found in TANAP in the High Tatras in the Batizovská dolina and Červená dolinka valleys $\left(\chi^{2}\right.$, $p<0.001)$. The prevalence in other parks was relatively balanced (Table 1,2). Statistical analysis of prevalence according to individual years showed no significant differences in individual years. When seasonal prevalence fluc- spring and autumn periods (Table 5, Fig. 2, 3).

Analyses of infection levels in chamois among the sites based on the mean number of L1 larvae in faeces confirmed similar levels of infection in the Belianske Tatras and the Slovak Paradise biotope, including the Červená dolinka valley in the High Tatras. In other sites (the High Tatras, the West Tatras, the Low Tatras, the Vel'ká Fatra

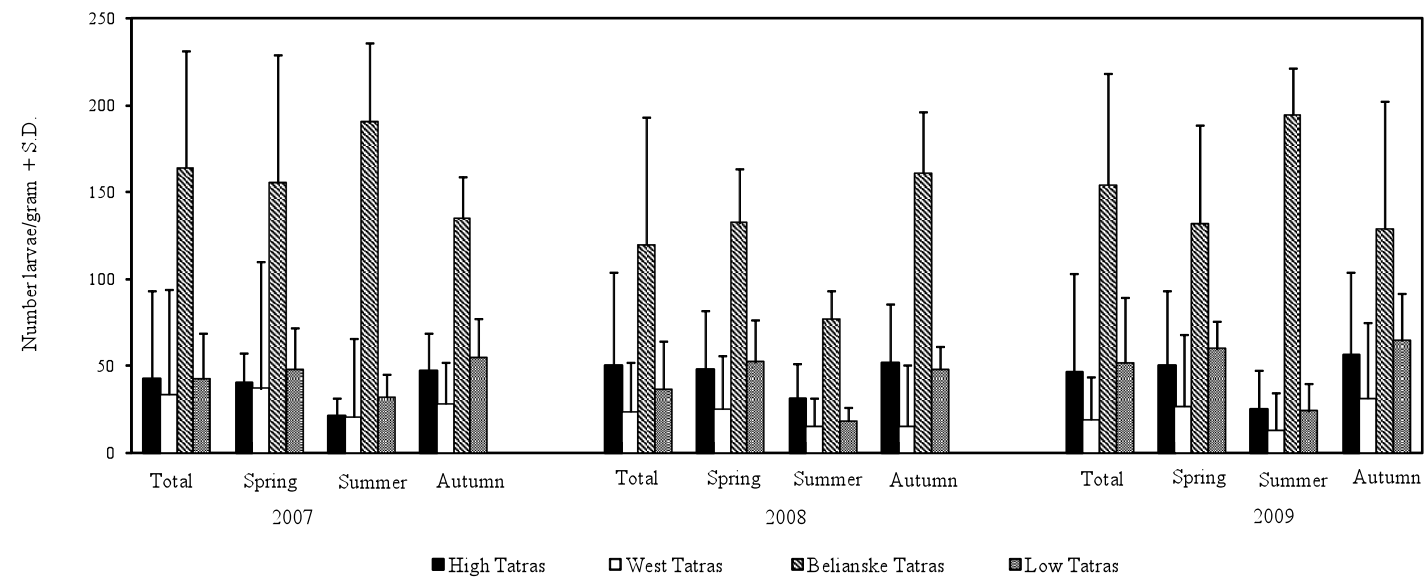

Fig. 2. Mean larvae L1 per gram faeces from chamois habitats in TANAP and NAPANT by years and seasons 


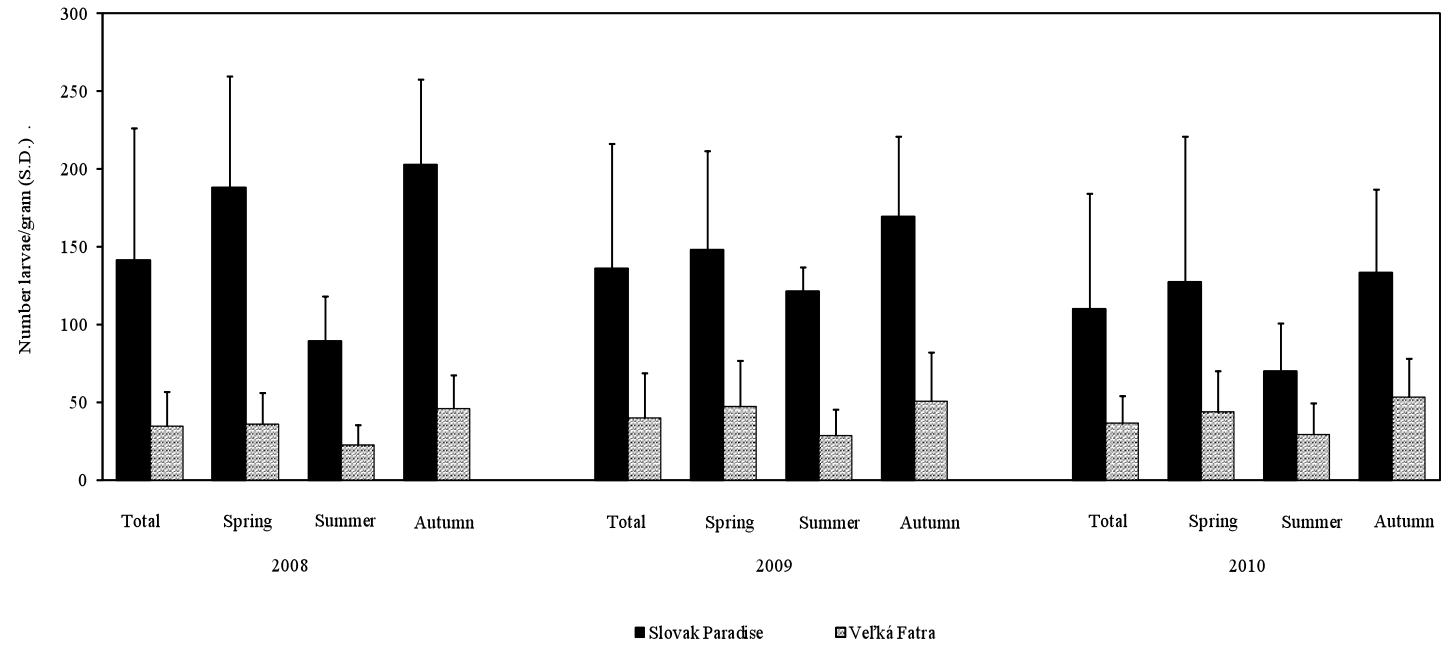

Fig. 3. Mean larvae L1 per gram of faeces from the chamois habitats in NAPSR and NAPVF by years and seasons

mountains) the levels of infection were less uniform (Fig. 4). The levels of chamois infection in lung tissue showed similar tendency of infection than in faeces; the mean number of L1 larvae per gram lung tissue in all dissected lungs ranged from $79.2 \pm 65.3$ to $598.3 \pm 732.9$. Overall, the Alpine chamois was more heavily infected than the Tatra subspecies (t-test, $\mathrm{p}<0.001$ ).

\section{Discussion}

An evaluation of current helminth status of lung nematodes in chamois with regards to ongoing climate changes has confirmed the presence of the same nematode species at all national parks of Slovakia as in the previous surveyed period. While during $2008-2010$ Muellerius spp. was the

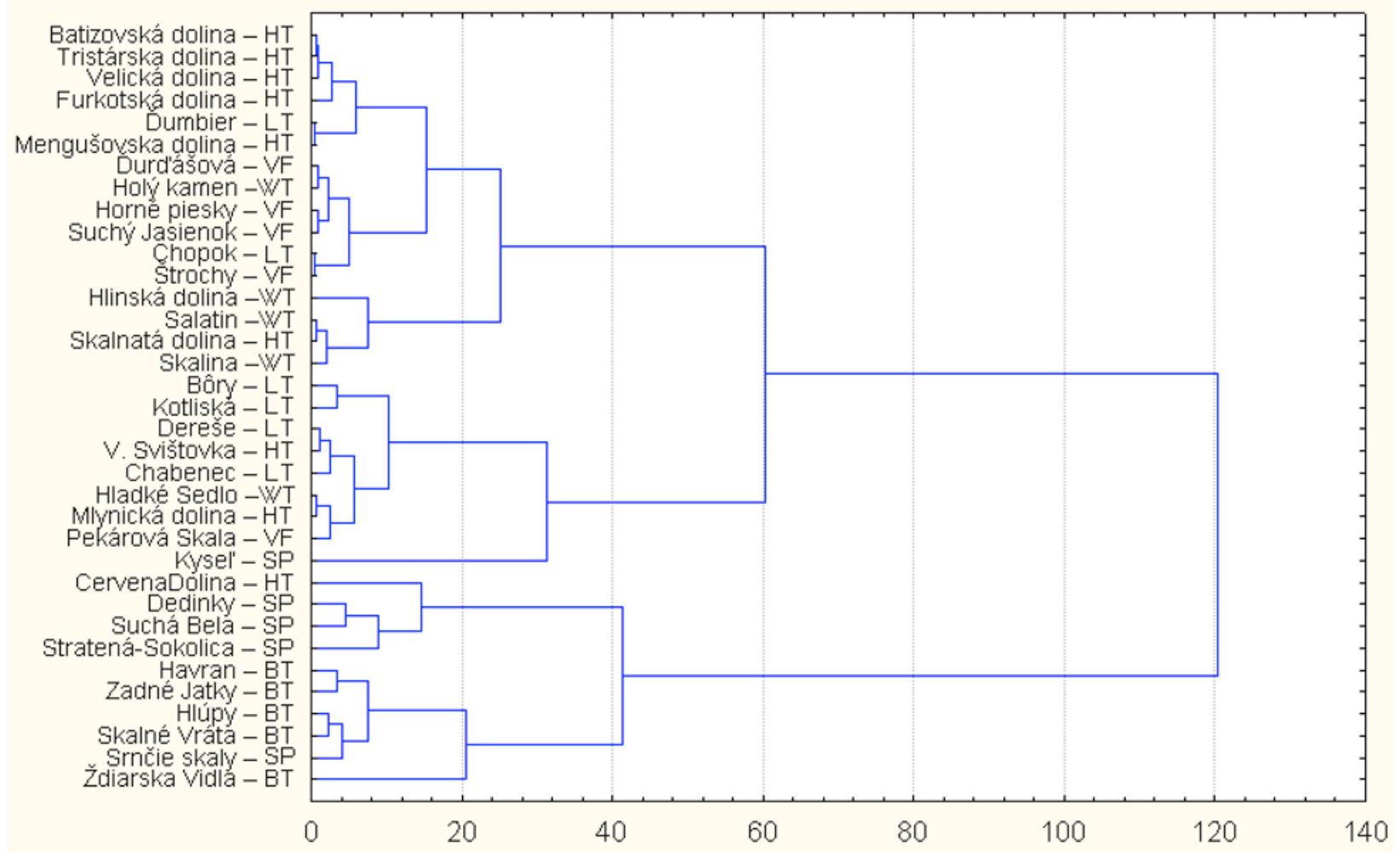

Fig. 4. Cluster analysis biotops' medians using Complete linkage (Furthest neighbor) with Euclidean distance measure. (HT - High Tatras, WT West Tatras, BT - Belianske Tatras, LT - Low Tatras, SP - Slovak Paradise, VT - Vel'ká Fatra) 
predominant species at all TANAP areas, during 1977 1980 it prevailed in the High and West Tatras and N. linearis was dominant in the Belianske Tatras. In 1997 the similar pattern was observed in these areas than at present (Sattlerová-Štefančíková, 1982; Štefančíková et al. 1999). Likewise, nowadays Muellerius spp. are dominant in NAPANT, though during 1981 - 1988 we detected only two Muellerius species in the lungs and faeces. In this territory $N$. linearis was detected in 1998, less frequently than both Muellerius species. This may be due to the fact that the chamois introduced from the High Tatras to the Low Tatras during 1981 - 1988 did not harbour this nematode species. It might have been transmitted from the Alpine chamois living in the Slovak Paradise and Vel'ká Fatra mountain range, from which the chamois migrated into zones adjacent to the areas of Tatra chamois in NAPANT.

Proportion patterns of lung nematode species in Alpine chamois in NAPSR and NAPVF were rather similar (Sattlerová-Štefančíková, 1982, 1987, 2005; Štefančíková, 1994, 1999). The sporadic occurrence of D. viviparus in NAPSR may be due to transmission from roe and red deer as their biotopes overlap (Štefančíková, 1994, 1999). Alpine chamois are often seen migrating into adjacent sheep pastures that increases the risk of mutual exchange of $M$. capillaris and $N$. linearis, which has been proven by detection in the faeces collected from the pastures. Hence, our data can be extrapolated to a broader epizotoological meaning. Chroust (1991) reported a predominance of both Muellerius species in Jeseníky, whereas Kotrlá et al. (1984) in Lužické mountains, Jeseníky, Česká Kamenica and High Tatras, Hörning (1975) in Switzerland, Kutzer \& Hinaidy (1969) and Stroh (1936) in Austria, Diez et al. (1987, 1990) in Spain, and Nocture et. al. (1998) in France reported $N$. linearis as the prevailing species. In the territory of Austria (Gebauer, 1932; Kutzer \& Hinaidy, 1969), Germany (Stroh, 1936; Salzmann \& Hörning, 1974), France (Hugonnet \& Euzéby, 1980), Italy (Balbo, 1973; Balbo et al., 1975; Genchi et al., 1984; Cancrini et al., 1985), Slovenia (Bidoveč et al., 1985), Spain (Diez et al., 1987, 1990), Russia (Pupkov, 1971) besides M. capillaris, $M$. tenuispiculatus and $N$. linearis, species of the genus Protostrongylus are also documented as common parasites in chamois. Neither us nor the above mentioned authors who studied the helminth fauna of Alpine chamois in Slovakia and the Czech Republic detected any Protostrongylus parasites. It seems that either these pathogens did not parasitize the lungs of introduced chamois or the conditions were unfavourable to their development and survival.

Data introduced here showed an increasing trend in the prevalence of lung nematodes in chamois herds in TANAP (83.3 \%). During 1977 - 1980 the prevalence reached $100 \%$ (Sattlerová-Štefančíková, 1982, 1987, 2005), but in 1997 only $48.4 \%$ of chamois were infected (Štefančíková et al., 1999). Prevalence of lung nematodes in NAPANT was similar to that of previous period $(86.0 \%, 88.5 \%)$. Unlike this, in NAPSR the prevalence was significantly increased
(97.2\%) when compared to our data collected during 1984 - $1993(57.7 \%)$ and was substantially higher than values reported by Krokavec Sr. and Krokavec Jr. (1991) (40.7 $\%$ ), Ciberej et al. (1997) (40.9\%) in chamois from the Slovak Paradise, (Chroust, 1991) in Alpine chamois from Jeseník (in the lungs $41.2 \%$, in the faeces $52.4 \%$ ), Nocture et al. (1998) in the French Alps in Bauges reserve (35.3\%), Salzman \& Hörning (1974) in the German Alps (33.6/8.3\%), Cancrini et al. (1985) in the Italian Alps in the Abruzzo reserve (47.6\%). In addition, the prevalence was similar as that recorded by Stroh (1936) in the German Alps (98\%) and Genchi et al. (1984) in the Italian Alps in the Val Belviso reserve (95\%). Similarly, in NAPVF we recorded a moderate increase in the prevalence from $78.4 \%$ to the current value of $84.5 \%$ (Sattlerová-Štefančíková, 2005).

Concerning the mean number of L1 larvae per gram of faeces in TANAP, we recorded a significant increase when compared to 1997 , when the number was low (7.9). In the Belianske Tatras the value reached the level from 1977 1980, when the number of L1 larvae in the High, West and Belianske Tatras was high during seasons of the year (Sattlerová-Štefančíková, 1987; Štefančíková et al., 1999). In NAPANT and NAPVF, the level of chamois infection remained moderate and in NAPSR it remained high. Seasonal fluctuation in the incidence of lung nematodes, recorded in the studied national parks, corresponds with the findings of Hugonnet \& Euzéby (1980), Hugonnet et al. (1981), Nocture et al. (1998), Diez et al. (1990), but contradicts to both our findings from TANAP during 1977 - 1980 when high and stable number of L1 larvae during all seasons (>100 larvae per $\mathrm{g}$ faeces) was observed, and from 1997 when we recorded higher level of infection during summer (Sattlerová-Štefančíková, 1987; Štefančíková et al., 1999).

Differences in the helminth composition, prevalences and level of infection in chamois are influenced by a number of ecological factors, such as geographic, geomorphological, climatic and trophic conditions of the biotopes, along with host migration and the occurrence of intermediate hosts.

The biotopes of the High Tatras differ from those of the Belianske Tatras in having a significant effect on the structure and density of the mollusc fauna. The granite bottom of the High and West Tatras with a continuous belt of spruce forests, producing acid substrate does not provide favourable living conditions for snails. Their abundance and species diversity are decreasing with the higher altitude and in the Alpine zone (approx. $1800 \mathrm{~m}$ above sea level) the snails are scarcely found on the granite. On the other hand, in the limestone part of the Belianske Tatras, the species diversity is quite rich with a strong snail population. The snails in this area ascend to the high altitudes in the Alpine zone over $2000 \mathrm{~m}$ above sea level, and on the tops of the mountain peaks, either hiding in the rock screes or basking in the sun (Ložek, 1974; Sattlerová-Štefančíková, 1987). The areas covered with parched and decomposed plants afford owing to their air-thermal isolation suitable place for snail hibernation and it can be found in these areas even when they are covered by snow during 
June, when at lower locations of chamois pastures new vegetation already emerges, while higher locations are under snow. The chamois become infected in the High and West Tatras mostly during seasonal migrations, in particular in spring, when they tend to descend to the lower altitudes because of food seeking and irregular migrations during the tourist season. These observations are supported by the determined prevalence of lung nematodes in chamois herds, which varied in different localities of this part of the Tatras. Conversely, in the Belianske Tatras the prevalence in different seasons has not varied so much as the infections can occur throughout the whole year. Increased level of infection in the Črvená dolinka valley (a part of the High Tatras) may be implied by its neighbourhood the Belianske Tatras given that during seasonal migration the chamois from this area often migrate into the valley.

The status of lung nematodes in chamois of TANAP is determined by several factors. Harsh climatic conditions occurring over several years at the time of the birth coupled with the presence of predators and increasing anthropic interference have decimated the chamois population. While in 1964 - 1967 chamois population reached 600 , in 2000 it was only 160 . The strong contamination of environment (toxic metal substances) has led to the decline of biodiversity of trophic base of chamois that contributed to the decrease of reproduction of chamois population, its vitality and resistance. Its impact on the gene pool of chamois is still unravelled. Preliminary results using genetic markers, microsatellites, DRB gene (MHC class II), and D-loop (mDNA) revealed low genetic variability and possible relative hybridism in the High Tatras population (Zemanová et. al., 2007). The decreased resistance has resulted in disturbance of host-parasite balance as a consequence of previous strong infections that contributed to the decrease in the chamois population and in turn to the lower dissemination of the lungworm propagative stages into the environment. These factors have delimited the infectivity of the intermediate and definitive hosts and consequently the infection rate in 1997 was lower than that recorded 20 years ago (Sattlerová-Štefančíková, 1987, 2005; Štefančíková et al., 1999).

At present, a rising trend of infection burden is apparent that is influenced by increased protection of the chamois activity implying the increased spatial cumulation of animals. This leads to the higher dissemination of propagative stages into environment and consequently the increased infectivity of intermediate and definitive hosts and infectivity rate.

The geomorphologic and climatic features of the chamois biotopes in both High and Low Tatras are similar, the only higher difference between them is the absence of calciphile plants in the current area of chamois distribution in the Low Tatras, since the area is free of limestone-dolomite substrate. This affects both the chamois trophic base and the occurrence of snails - the intermediate hosts of lungworms. They are abundant mainly in lower zones, but towards the alpine zone the number of snails is rapidly decreasing and over $1500 \mathrm{~m}$ above sea level they occur only sporadically. The moderate degree of infection in chamois in this reservation showed that animals are predominantly infected during their seasonal migrations, when they descend into lower altitudes, below the upper forest line, mainly in spring (but also throughout the whole year during irregular migrations) (Štefančíková, 1994). Rather rugged terrain of the Slovak Paradise, temperature and humidity differences between cold and humid canyons and sun-exposed rocks with a warm and nutrient rich limestone base determine the abundance and species diversity of plant cover, which is also reflected in the numerous populations and species composition of malacofauna. Similarly, in the National Park of Vel'ká Fatra dolomitic and limestone substrates create suitable living conditions for the snails, thus increasing possibility for chamois to become infected with lung nematodes (Štefančíková, 1999; Sattlerová-Štefančíková, 2005).

According to climate change reports of the Slovak Hydrometeorological Institute, mean air temperature in Slovakia has risen by over $1{ }^{\circ} \mathrm{C}$ during the period of $1980-2004$. This increment is close to the approx. $1.5^{\circ} \mathrm{C}$ increase in mean annual temperature observed over the whole $20^{\text {th }}$ century (Balajka et al., 2005). Under the Central European conditions, mean air temperature decreases with altitude by cca $0.6^{\circ} \mathrm{C}$ for each $100 \mathrm{~m}$, which means that since $1980 \mathrm{~s}$ temperature zones could have risen by almost $200 \mathrm{~m}$ in the mountainous areas. These global climatic changes are involved in increasing the infectivity rate, which is reflected in the protraction of survival time of larvae L1 in the environment and the accelerated development of larvae in intermediate hosts-snails.

The variety of snail species in the all Slovak National Parks and their great ability to serve as the intermediate hosts of lung nematodes in different biotopes afford favourable conditions for the development of lung nematodes. Long lifetime and immense reproduction abilities of parasites in the lung, striking resistance of L1 larvae in the environment, and opportunity to hibernate in snails enable their persistence in all chamois biotopes in Slovakia.

\section{Acknowledgements}

We gratefully acknowledge the help of guards of National Parks. We are grateful to Juraj Ksiažek, Jozef Kormančík, Jozef Ballo, L’udovít Remeník for provided necropsies and faecal samples. Work was supported by the Slovak Grant Agency VEGA, Grant No. 2/0042/08 and within a frame of the project Centre of Excellence for Parasitology (Code ITMS: 26220120022) based on the support of the Operational Programme "Research \& Development" funded from the European Regional Development Fund (rate 0.2).

\section{References}

Aulagnier, S., Giannatos, G., Herrero, J. (2008): Rupicapra rupicapra. In: IUCN 2010. IUCN Red List of Threatened Species. Version 2010.1. Retrieved June 23, 2010 from http://www.iucnredlist.org. 
BAlaJKA, J., LAPIN, M., MindÁŠ, J., ŠŤAstnÝ, P., ThalmainerovÁ, D. (2005): The Fourth National Communication of the Slovak Republic on Climate Change. Slovak Ministry of Environment. Available at http:// unfccc.int/resource/docs/natc/slknc4.pdf.

BALBO, T. (1973): Indagini sulla situazione parassitologica nei mammiferi del Parco Nazionale del Gran Paradiso. Parasitologia, 15: $301-312$

Balbo, T., Costantini, R., Peracino, V. (1975): Indagini sulla diffusione dei nematodi polmonari nello stambecco (Capra ibex) e nel camoscio (Rupicapra rupicapra) del Parco Nationale del gran Paradiso e della Riserva di Valdieri. Parasitologia, 17: 65 - 68

BidoveČ, A., VAlentinič, S., Kuses, M. (1985): Parasitic pneumonia in chamois (Rupicapra rupicapra $\mathrm{L}$ ) in Slovenia. In: LOVARY, S. (Ed) The Biology and management of mountain ungulates. Croom Helm., London, pp. 240 - 242 Blahout, M. (1976): Chamois game. Príroda, Bratislava, 171 pp. (In Slovak)

BlahouT, M. (1977): Some anthropic effects on chamois in the Tatras National Park. In Proceedings "Studies of TANAP”, Osveta Martin, 19: 127 -168, (In Slovak)

CANCRINI, G., IORI, A., Rossi, L., FicO, R. (1985): Occurence of pulmonari and gastrointestinal nematodes in the Abruzzo chamois. In: LOVARY S. (Ed) The Biology and management of mountain ungulates. Croom Helm., London, pp. $256-257$

CAPRINAE SPECIALIST GROUP 2000. Rupicapra rupicapra ssp. tatrica. In: IUCN 2006. 2006 IUCN Red List of Threatened Species. Retrieved on April 21, 2007 from http://www.iucnredlist.org

Chroust, K. (1991): Parasite fauna of chamois in Jeseníky. Folia venatoria, 21: 77 - 88 (In Czech)

CibereJ, J., LetKovÁ, V., KAČÚR, M. (1997): Helminth fauna of alpine chamois (Rupicapra rupucapra rupicapra) in area Paradise. Slov. Vet. J., 22 (6): $301-302$

Clark, W. C., Clarke C. M. H. (1981): Parasites of chamois in New Zeland. New Zeland Vet. J. 29, 144

Diez, P., Diez, N., Anton, A., Morrondo, M. P. (1987): Principales problemas parasitarios del rebeco en la Cordillera Cantábrica. Actas de las Jornadas de Estudio sobre la Montaňa. Edit. URZ, 337 - 350

Diez, P., Diez, N., Morrondo, P., Cordero, M. (1990): Broncho-pulmonary helminths of chamois (Rupicapra rupicapra parva) captured in north.west Spain: assessment from first stage larvae in faeces and lungs. Ann. Parasitol. Hum. Comp., 65(2): $74-79$

GAŠINEC, I. (2002): Eliminating the impact of negative anthropogenic factors on decrease in the Tatra Chamois population in Tatras National Park. In: JANIGA M., ŠVAJDA J. (Eds) Chamois protection. TANAP, NAPANT, IHAB, Tatranská Štrba, Banská Bystrica, Tatranská Javorina, 217 $-228$

Gebauer, O. (1932): Zur Kenntnis der Parasitenfauna der Gemse. Zeitsch. Parasit. 4 (2): 147-219.

Genchi, C., MANFredi, M. T., Sioli, C. (1984): Les infestation naturelles des chévres par les strongyles pulmonaires en milieu Alpin. In: Les maladies de la chevre, Niort
(France), 9 - 11 octobre, 1984, INRA 28: $347-352$

HoudEK, I., BOHUŠ, I. (1976): The story of the Tatras. Šport, Bratislava, 241 pp. (In Slovak)

HöRNING, B. (1975): Die rolle des Parasitenbefalls in den Wildbeständen. Schweiz. Zeitsch. Forstwesen 5: $361-372$

HÖRNING, B., WANDELER, A. (1968): Der Lungenwurmbefall von Reh und Gemse in einigen Gebieten der Schweiz. Rev. Suis. Zool. 75: $597-608$

HugONNET, L., EuZÉBY, J. (1980): La parasitisme chez les jeunes chamois de la réserve naturelle des Bauges. Bull. Acad. Vet. France, 53: $77-85$

Hugonnet, L., Montagut, G., EuzéBy, J. (1981): Incidences réciproques des infestations helminthiques des ruminants sauvages et des ovins domestiques en alpage en Vanoise. Bull. Soc. Sci. Vet. Med. Com. Lyon, 83: $193-199$ Kotrlá, B., ČERnÝ, V., Kotrlý, A., MinÁŘ, J., RYŠAvÝ, B., ŠEBEK, Z. (1984): Parasitoses of game. Edition Academia Praha, 191 pp.

Krokavec, M. JR., KroKavec, M. SR. (1991): Helminth fauna of Alpine chamois in the Slovak Paradise. Veterinářství, 41(3 - 4): 76 - 77 (In Slovak)

Kutzer, E., Hinaidy, H. K. (1969): Die Parasiten der wildlebenden Wiederkäuer Österreichs. Zeitsch. Parasit. 32: $354-368$

LOžEK, V. (1974): The Key to molluscs of Czechoslovakia. Edition SAS, Bratislava, 289 pp. (In Slovak)

Nocture, M., Cabaret, J., Hugonnet-Chapelle, L. (1998): Protostrongylid nematode infection of chamois (Rupicapra rupicapra) at the Bauges massif. (French Alps). Vet. Parasitol. 77: 153 - 161. DOI: 10.1016/S03044017(97)00053-8

PANAYTOVA-PENCHEVA, M. S. (2006): New records of protostrongylid lungworms from wild ruminants in Bulgaria. Vet. Med. 51(10): 477 - 484

PUPKOV, P.M., (1971): Helminth fauna of Rupicapra rupicapra caucasica in Central Caucasus. In: Trudy Gorskogo Gel'skohozyaistvennogo Inst. Yubileinyi., 32: 331 - 333 (In Russian)

RADÚCH, J., KARČ, P. (1981): Current status and prospects of chamois population in the Low Tatras National Park. In: Proceeding of Current status and prospects of introduced populations of Tatra chamois in Slovakia. Publ. House Technol. ČSVTS Banská Bystrica, pp. 7 - 30 (In Slovak) RADÚCH, J. (2002): The importance of predators in the ecology of the Tatra chamois. In: JANIGA M., ŠVAJDA J. (Eds.) Chamois protection. TANAP, NAPANT, IHAB, Tatranská Štrba, Banská Bystrica, Tatranská Javorina, pp. $56-66$

SAlzMAN, H. C., HöRning, B. (1974): Der parasitologische Zustand von Gemspopulationen des Schweizarischen Juras im Vergleich zu Alpengemsen. Zeitsch. Jagdwiss. 20: 105 - 115

SATTLEROVÁ-ŠTEFANČíKOVÁ, A. (1982): The resistance of first stage larvae of Muellerius spp. and Neostrongylus linearis (from the feces of chamois, Rupicapra $r$. tatrica) to different physical factors under laboratory and natural conditions. Helminthologia. 19: $151-160$

SATTLEROVÁ-ŠTEFANČÍKOVÁ, A. (1987): Ecological con- 
ditions for lungworm infections of chamois in the Tatra National Park. Biológia (Bratislava), 42: 113 - 119

SATTLEROVÁ-ŠTEFANČíKOVÁ, A. (2005): Chamois and its parasites. PressPrint, Košice, 124 pp. (In Slovak, summary in English).

StATSOFT InC.: STATISTICA (Data Analysis Software System), Version 6, 2001, http://statsoft.com

STROH, G. (1936): Lungenwurmfunde bei 100 Gemsen und ihre Krankmachende Bedeutung. Berl. Tierärz. Wschr. 43: $696-699$

ŠTEFANČíKOVÁ, A. (1994): Lung nematodes of chamois in the Low Tatra National Park, Slovakia. J. Helminthol. 68: $347-351$
ŠTEFANČíKOVÁ, A. (1999): Lung nematodes in chamois (Rupicapra rupicapra rupicapra) of the Slovak Paradise National Park. Acta Parasitol. 44(4): 255 - 260

ŠTeFanČíKOVÁ, A., ChOVANCOVÁ, B., DuBINSKÝ P., TOMAŠOVIČOVÁ, O., ČORBA, J., KÖNIGOVÁ, B., HOVORKA, I., VASILKOVÁ, Z. (1999): Lung nematodes of chamois (Rupicapra rupicapra tatrica) from the Tatra National Park, Slovakia. J. Helminthol. 73: 259 - 263

ZemanovÁ, B, HáJKovÁ, P, BRyJA, J, MiKulíčEK, P, MARTínKovÁ, N, HÁJEK, B., ZIMA, J.( 2007): Conservation genetics of chamois populations in Slovakia. In: Prigioni C., SFORZI A (Eds). Abstracts V European Congress of Mammalogy. Hystrix It. J. Mamm. (ns) Vol 1 - 2, Suppl. (2007), 28 pp.

ACCEPTED JUNE 6, 2011 